\author{
Katarzyna Wereszczyńska \\ ORCID: 0000-0002-8175-882X
}

\title{
Tożsamość i tożsamość obywatelska jako zadanie dla edukacji
}

\section{Wprowadzenie}

W rzeczywistości zmieniającej się dynamicznie pod wpływem zjawisk: politycznych, społecznych i kulturowych, reguł ekonomii wolnego rynku, otwartości na świat, komunikacji elektronicznej, Internetu tworzy się przestrzeń, w której człowiek może odczuwać niepewność bytu, zagubienie, a w samoocenie deficyt takich cech, które mogłyby wyposażać go w siłę do współczesnych warunków życia. Człowiek, podejmując trud określania „kim jest?” i odczytywania cech wyznaczających poczucie tożsamości - „ja”, odrębności i niepowtarzalności wśród innych ludzi oraz planując swój byt zmuszony jest tworzyć go elastycznie, uwzględniając nowe wyzwania wynikające z nieustannych zmian w „płynnej nowoczesności”. To trudne zadanie o znaczeniu całożyciowym łączy się ściśle z projektowaniem i dostosowywaniem wymiaru poczucia tożsamości. Może być realizowane na podstawie autorefleksji oraz doświadczeń własnych, jak i ofert, porównań i ocen pochodzących z kręgu rodziny, sfery społecznej i infrastruktury cywilizacyjnej. Ochrona cech tożsamości identyfikujących wyłącznie daną osobę z zachowaniem tych, które nadają spójność, wartość, sens jej

$1 \quad$ Z. Bauman, 44 listy ze świata płynnej nowoczesności, Wydawnictwo Literackie, Kraków 2011, s. 5-6. 
życiu oraz dopełnienie tego autonomicznego pierwotnego konstruktu o nowe znaczenia, wartości i sensy wymagają uzyskiwania zdolności do aktywnego poszukiwania i twórczego doskonalenia tożsamości. W tym działaniu wspomaganie i budowanie oparcia powinno być zadaniem realizowanym również $\mathrm{w}$ ramach edukacji, w całym toku kształcenia i wychowania, w którym jednostka uczestniczy.

Mirosław J. Szymański, w wypowiedzi na temat tożsamości jako zadania w czasach gwałtownej zmiany społecznej, kiedy jednostka podejmuje wysiłek „ciągłego kształtowania własnego «ja»”, narażona jest na pokonywanie stanów, jakie przynosi niepewność i kryzysy, pisze: „Dlatego konstruowanie tożsamości staje się ważnym zadaniem jednostki i wymaga pedagogicznego wspomagania".

Tożsamość człowieka cechuje wiele wymiarów, składających się na wieloaspektową i wielopoziomową zintegrowaną całość, w określonych sytuacjach, w zależności od kontekstu społecznego „wobec różnych partnerów człowiek ukazuje ten aspekt tożsamości, który w danej sytuacji uważa za najbardziej adekwatny"3. To sprawia, że może podejmować różne role społeczne, być członkiem określonej zbiorowości, narodu, grupy wyznaniowej, zawodowej, obywatelem państwa czy członkiem organizacji w systemie, do którego należy. W sytuacjach społecznych, w działaniu, w relacjach i interakcjach z innymi jednostkami człowiek tworzy „obraz samego siebie wobec innych” i tożsamość wówczas staje się źródłem (p)odpowiedzi na pytania: „Kim jestem wobec innych ludzi?” i „Kim jestem wobec innych grup?”4.

W niniejszej wypowiedzi przyjęłam jako zadanie edukacyjne kształtowanie tożsamości, w szczegółowym ujęciu kształtowanie poczucia tożsamości obywatelskiej, uznając jej istotność w przygotowaniu jednostki do uczestnictwa w życiu publicznym państwa demokratycznego i bycia obywatelem. Ten wymiar tożsamości należy rozumieć jako adekwatny do oczekiwania od jednostki przyjmującej rolę obywatela, aby w poczuciu swej obywatelskości wraz z innymi mogła włączyć się w działania wspólne i potrzebne w tworzeniu dobra wspólnego.

2 M.J. Szymański, Kim jestem? Tożsamość jako zadanie w czasach gwałtownej zmiany społecznej, „Lubelski Rocznik Pedagogiczny” 2016, t. 35, z. 1, s. 11.

3 Z. Mach, Przedmowa, [w:] T. Paleczny, Socjologia tożsamości, Krakowskie Towarzystwo Edukacyjne Sp. z o. o., Oficyna Wydawnicza AFM, Kraków 2008, s. 9.

4 Ibidem. 
W konstruowaniu tożsamości obywatelskiej ważne jest, by jednostka, której wolność określa demokracja uzyskiwała zdolność i kondycję wyznaczania sobie granic korzystania z tej wartości oraz podejmowała zadania, jakim będzie zdolna odpowiedzialnie sprostać. W poczuciu indywidualności wobec wspólnoty obywatelskiej, w wyzwalaniu świadomości siły swego sprawstwa w tworzeniu i współtworzeniu porządku społecznego, jednostkę powinna wzmacniać edukacja obywatelska.

Problematykę wymienioną w temacie niniejszej wypowiedzi ujmuję w dwu częściach. W pierwszej nawiązuję do pojęć tożsamość i tożsamość obywatelska i przedstawiam ich wybrane znaczenia na podstawie ujęć teoretycznych, definicyjnych oraz interpretacji. Do omówienia wybrałam zagadnienie kształtowania tożsamości obywatelskiej młodego pokolenia, to jest młodzieży u progu dorosłości. Jako zakres edukacji, mającej wspierać kształtowanie tożsamości obywatelskiej przyjęłam wychowanie obywatelskie. Z tą też problematyką łączy się druga część wypowiedzi.

\section{Tożsamość i tożsamość obywatelska - wybór znaczeń w ujęciach teoretycznych i interpretacjach}

Tożsamość, to jedno z pojęć występujące w obrębie problematyki dotyczącej człowieka i jego personalizacji, jednostki w otoczeniu społecznym, należącej do wspólnoty, grupy społecznej o określonej kulturze. Termin pochodzi od słowa łacińskiego idem - ten sam, ten$\dot{z} \mathrm{e}^{5}$. W języku angielskim dla jego określenia stosowane jest identity „identyczność, tożsamość”, a jako czasownik przechodni znaczy też: „utożsamiać, identyfikować, rozpoznać”. W polskim słownictwie oznacza „bycie tym samym; identyczność; tożsamość cech”. Przy haśle identyczny, wyodrębnionym w Słowniku języka polskiego znajdujemy również określenie bliskoznaczne tożsamości - „taki sam, jednakowy,

5 Słownik łacińsko-polski, według Słownika H. Mengego i H. Kopii, oprac. K. Kumaniecki, PWN, Warszawa 1964, s. 239.

6 T. Grzebieniowski, Ilustrowany słownik angielsko-polski, polsko-angielski, Państwowe Wydawnictwo Wiedza Powszechna, Warszawa 1979, s. 196.

$7 \quad$ Słownik języka polskiego, t. 3, PWN, Warszawa 1981, s. 519; por. Słownik 100 tysięcy potrzebnych słów, J. Bralczyk (red.), Wydawnictwo Naukowe PWN, Warszawa 2005, s. 853. 
niezmienny"8. Zamieszczona jest także w dwu ujęciach identyfikacja. W pierwszym, jest to „stwierdzenie czyjejś tożsamości, ustalenie jednakowości czegoś, w porównaniu z czymś (...)", w drugim, psychologicznym, wiąże się z upodabnianiem „własnej osobowości do jakiegoś wybranego wzorca osobowości", z wartościami moralnymi, postawą ideową, sposobami postępowania przejmowanymi „od kogoś”. Wymienione określenia przypisywane tożsamości wskazują, że w jej interpretowaniu można odnajdywać różne ujęcia. Do kręgu znaczeń łączących się z koncepcją rozwoju człowieka termin tożsamość wprowadził Erik H. Erikson, wyrażając pogląd, że jest ona „subiektywnym poczuciem ciągłości istnienia i spójną pamięcią" ${ }^{10}$. Interpretując rozwój człowieka Erikson nawiązał do pojęcia „Ego” i określił je „wewnętrzną instancją” mającą strzec owego porządku wewnętrznego jednostki, od którego zależy porządek w świecie zewnętrznym ${ }^{11}$. Współcześnie nadal poszukuje się wyjaśnień charakteru tożsamości i tego, co stanowi jej istotę. Z dotychczasowych rozważań teoretyczno-metodologicznych wynika, że tożsamość jest pojęciem ujmowanym w następujących kategoriach: zjawiska, fenomenu, procesu, konstruktu ${ }^{12}$. Najczęściej jednak opisywana jest jako proces upodabniania się i identyfikowania z kimś lub czymśs, stan bycia i świadomość, element osobowości, podobieństwo lub odrębność, „jedność z czymś”, też „zasada porządkowania/klasyfikacji świata społecznego"13. Jak nadmienia Katarzyna Waszczyńska - liczne, zróżnicowane podejścia i koncepcje interpretacyjne przyczyniły się do nadania tożsamości wielu, często różnych, niespójnych charakterystyk ${ }^{14}$. Interpretując tożsamość Zbigniew Bokszański, nawiązał m.in. do jej wymiaru normatywnego i deskryptywnego. Pierwszy wymiar łą-

$8 \quad$ Słownik języka polskiego, t. 1, PWN, Warszawa 1978, s. 766.

9 Ibidem, s. 766.

10 E.H. Erikson, Identity. Psychosocial, [w:] D.L. Sills (red.), International Encyclopedia of The Social Science, t. 7, The MacMillan Company \& The Free Press, New York 1968, s. 61. Tłumaczenie polskie za Z. Machem, Przedmowa, [w:] T. Paleczny, Socjologia tożsamości..., s. 9.

11 E.H. Erikson, Dzieciństwo i społeczeństwo, tłum. P. Hejmej, Dom Wydawniczy REBIS, Poznań 1997, s. 204.

12 K. Waszczyńska, Wokół problematyki tożsamości, „Rocznik Towarzystwa Naukowego Płockiego" 2014, nr 6, s. 49-53.

13 Ibidem, s. 51. Por. G. Babiński, Pogranicze polsko-ukraińskie. Etniczność, zróżnicowanie religijne, tożsamość, Zakład Wydawniczy Nomos, Kraków 1997, s. 84.

14 K. Waszczyńska, Wokół problematyki tożsamości..., s. 49-50. 
czy z pojęciem człowieka w rozumieniu filozoficznym, istotą ludzką, pewnym stanem ukształtowania człowieka, w którym celowo „realizuje się sens jego egzystencji”, w deskryptywnym ujęciu podkreśla jej istotność oraz wyjaśnia - jak konstruuje się tożsamość i jak dynamicznie przebiega ten proces ${ }^{15}$. Natomiast Marian Golka uważa, że tożsamość ,jest kategorią na przecięciu jednostkowych podmiotów i struktur społecznych, subiektywności i obiektywności, wyborów i narzucania, własnej refleksyjności i doświadczeń społecznych"16. Z tych względów w interpretacjach tego pojęcia dokonuje się wyodrębnienia takich znaczeń, jak: tożsamość jednostkowa, określana też osobową lub osobistą i tożsamość społeczna, tożsamość grupowa i inne. W świetle dostępnych uzasadnień przyjmuje się, że w rozwoju człowieka kształtowanie się osobowości i tożsamości zachodzi w formie procesu, podczas którego następuje: definicyjne i identyfikacyjne opisywanie siebie; nabywanie wiedzy, sądów i przekonań, wzorów postaw i zachowań; odbywa się konstruowanie aksjologicznej konfiguracji systemu wartości, rozwijanie aktywności własnej, bazujące na potencjale biofizycznym oraz psychicznym, umiejscowione w określonym wymiarze czasu i przestrzeni rzeczywistości. Każdy z tych elementów można uznać za punkt odniesienia w tworzeniu zarówno tożsamości jednostkowej, jak i tożsamości społecznej. Tożsamość jednostkowa jest strukturą ruchliwą i dynamiczną ${ }^{17}$, elastyczną i płynną ${ }^{18}$, twórczą i konfrontującą się ${ }^{19}$, przekształcającą się, powstającą w dyskursie i wytwarzaną w toku życia człowieka ${ }^{20}$. Jak uważa Anthony Giddens, jest również „przedsięwzięciem refleksyjnym", jednostce wskazuje zadania ciągłej weryfikacji narracji biograficznej, dokonywania „wyborów spośród różnorakich opcji", co umożliwia jej wytwarzanie czegoś wyjątkowego i odmiennego,

15 Z. Bokszański, Tożsamości zbiorowe, Wydawnictwo Naukowe PWN, Warszawa 2006, s. 31-33.

16 M. Golka, Cywilizacja współczesna i globalne problemy, Oficyna Naukowa, Warszawa 2012, s. 302.

17 A. Giddens, Nowoczesność i tożsamość. „Ja” i społeczeństwo w epoce późnej nowoczesności, tłum. A. Szulżycka, Wydawnictwo Naukowe PWN, Warszawa 2010, s. 28.

18 Z. Bauman, 44 listy ze świata płynnej nowoczesności..., s. 5-6.

19 Idem, Ponowoczesne wzory osobowe, „Studia Socjologiczne” 1993, nr 2, s. 7-31.

20 B. Misztal, Teoria socjologiczna a praktyka społeczna, Wydawnictwo Universitas, Kraków 2000, s. 144-145. 
czym wyróżnia się od innych ${ }^{21}$. W katalogu elementów tworzących konstrukt tożsamości, Jowita Bartczak wyróżnia następujące: „pamięć zbiorowa, terytorium, język, system norm i wartości, systemy religijne i systemy władzy, przeszłość w postaci wydarzeń i wytworów kultury, przemiany mikro- i makrostruktur"22. Systematyzując składniki tożsamości jednostkowej, Golka umieszcza je w obszarach samowiedzy jednostki, samooceny i wiedzy o własnych potrzebach ${ }^{23}$. Człowiek jest istotą naturalnie dążącą do realizacji różnych celów i planów życiowych przez siebie określonych, związanych często z zaspokajaniem potrzeby przynależności i identyfikacji grupowej, aktywnością zawodową oraz realizacją aspiracji, podejmuje różne role, również te wiążące się z funkcjonowaniem w sferze społecznej i politycznej24. To wówczas kształtują się tożsamości społeczne jako konstrukty wielowarstwowe i wtórne, które Giddens opisuje jako „nakładające się na pierwotne”, stwierdzając, że struktura tożsamości społecznych ma charakter złożony, płynny, zmienny, co wywołane jest „przyjmowaniem nowych ról i porzucaniem starych"25. Obok poczucia „ja” jako indywidualności biopsychicznej, tożsamość społeczna stanowi równie ważny składnik tożsamości człowieka, dzięki niej zatem może określać swoją przynależność do jakiejś grupy. W wymiarze indywidualnym jest sposobem definiowania siebie kategoriami uznawanymi w danej społeczności, w wymiarze grupowym natomiast jest efektem relacji międzyosobowych członków danej grupy, umożliwia jednostce ustalanie odpowiedzi na pytania „kim jestem w stosunku do innych ludzi?» lub «kim jest moja grupa w stosunku do innych grup?»"26. Wśród bardzo licznych definicji tożsamości próby określania tożsamości obywatelskiej i interpretowania jej znaczenia podejmowane były dotychczas stosunkowo rzadko. Tę kategorię można by ujmować jako rodzaj tożsamości

21 A. Giddens, Ph.W. Sutton, Socjologia. Wydanie nowe, tłum. O. Siara, A. Szulżycka, P. Tomanek, Wydawnictwo Naukowe PWN, Warszawa 2012, s. 257.

22 J. Bartczak, Wymiary tożsamości, [w:] A. Firkowska-Mankiewicz, T. Kanash, E. Tarkowska (red.), Krótkie wykłady z socjologii. Kategorie, problemy, subdyscypliny, t. 2: kontynuacja, Wydawnictwo Akademii Pedagogiki Specjalnej im. Marii Grzegorzewskiej, Warszawa 2010, s. 28.

23 M. Golka, Cywilizacja współczesna i globalne problemy..., s. 304-305.

24 A. Giddens, Ph.W. Sutton, Socjologia. Wydanie nowe..., s. 257.

25 Ibidem.

26 Z. Mach, Procesy rekonstrukcji tożsamości społecznej w krajach Europy Środkowo-Wschodniej, „Nomos” 1994, nr 7/8, s. 10. 
zbiorowej, społecznej, łączyć również z tożsamością narodową. Nie jest to jednak uzasadnione, czego dowodzi argumentacja Antoniny Kłoskowskiej, że „żadna zbiorowość społeczna, do której można byłoby odnieść pojęcie tożsamość nie ma psychicznego organu samowiedzy produkującego coś, co można byłoby uznać za ścisły odpowiednik samoświadomości osobniczej"27. Starając się pojęcie tożsamość obywatelska włączyć w krąg rodzajowy tożsamości, jej zakres znaczeniowy można postrzegać jako najbliższy poczucia obywatelskości. Do takiego podejścia skłania uzasadnienie rozumienia obywatelskości sformułowane przez Edwarda A. Shilsa. Uznaje on, że choć obywatelskość jest dyspozycją cechującą społeczeństwo obywatelskie, to jest również swoistym światopoglądem, „postawą, w której osobowość jednostki świadomie przyzwala na jej uczestnictwo w osobowości zbiorowej, ograniczającej i kształtującej jej decyzje i działania", w jej konstruowaniu widzi rolę oświaty, wiedzy o społeczeństwie i jego historii ${ }^{28}$. U jednostki włączającej się aktywnie w życie społeczne i polityczne, nieobojętnej na zjawiska występujące w rzeczywistości, świadomej i przekonanej o ważnym znaczeniu wartości społecznych, uznającej cnoty obywatelskie jako podstawowy wyznacznik norm i zasad postępowania obywatela, może budzić się poczucie indywidualnej, typowej dla niej tożsamości obywatelskiej. Ten szczególny atrybut tożsamości jednostki może wynikać też z samooceny własnego zaangażowania oraz zachowań i relacji z uczestnikami życia publicznego. Powinien kształtować się również w najbliższym otoczeniu rodziny, w miejscu zamieszkania, a przede wszystkim w toku wychowania obywatelskiego w szkole z udziałem nauczycieli.

Współcześnie podkreśla się, że rosnąca dynamika życia społecznego i towarzyszące jej takie zjawiska jak fragmentaryzacja, zmienność, niestałość mają również istotne znaczenie w określaniu - kim jestem? Jaka jest moja tożsamość obywatelska? Jej poczucie przyjmuje dziś częściej postać obywatelskości lokalnej (obywatel miasta, obywatel regionu) i przejawia się głębszym zaangażowaniem w pielęgnowanie

$\overline{27}$ A. Kłoskowska, Tożsamość i identyfikacja narodowa $w$ perspektywie historycznej i psychologicznej, „Kultura i Społeczeństwo” 1992, nr 1, s. 131-143.

28 E.A. Shils, Co to jest społeczeństwo obywatelskie?, tłum. D. Lachowska, [w:] K. Michalski (red.), Europa i społeczeństwo obywatelskie. Rozmowy w Castel Gandolfo, Wydawnictwo Znak, Kraków 1994, s. 8-9, 11. 
wartości, obyczajowości i tradycji lokalnych. Pod wpływem procesów globalizacyjnych, ułatwionej komunikacji, ludzie identyfikują się też ze społecznością Europy i świata i z tej perspektywy geokulturowej przypisują swej tożsamości określenie europejskiej lub globalnej. Stąd też coraz częściej występują pojęcia obywatel Europy, obywatel świata. Elżbieta Ozga, nawiązując do tej kwestii podkreśla zjawisko rozmywania się tożsamości obywatelskiej z współwystępowaniem szeroko oferowanych „tożsamości alternatywnych”, przy dużym wpływie wywieranym przez kulturę popularną i ideologię konsumpcji ${ }^{29}$. Zagrożeniem dla tożsamości obywatelskiej jest podporządkowanie regułom urynkowienia różnych sfer życia społecznego, ale też i życia prywatnego. Dominująca aktywność konsumpcyjna i medialna w społeczeństwie silnie determinuje tożsamości, szczególnie w wymiarze obywatelskim i politycznym ${ }^{30}$. Obecnie zauważyć można nasilenie znaczenia wartości narodowych, wyraźnie akcentujących się w bieżącej polityce oraz w odradzających ruchach nacjonalistycznych, w których uczestniczą często ludzie młodzi. Definiowanie tożsamości obywatelskiej dokonywane jest również na podbudowie tożsamości narodowej. Michał Bilewicz, w oparciu o realizowane badania nad zagadnieniem tożsamości narodowej zauważa, że tworzy się ona na podłożu poczucia pewności siebie członków danej grupy narodowej, ma dużą wartość mobilizującą i sprawczą wobec obywateli, którzy powinni odrzucić nastawienia ksenofobiczne, narcystyczne, kosmopolityczne oraz postawę wyłącznego utożsamiania się z lokalną społecznością ${ }^{31}$. W świetle różnych stanowisk przyjętych w definiowaniu tożsamości obywatelskiej czynię próbę nadania tej kategorii następującego własnego określenia, a mianowicie:

tożsamość obywatelską w perspektywie współczesnej można by interpretować jako: element tożsamości jednostkowej - osobistej, tworzącej

29 E. Ozga, O obywatelskości i jej przemianach na przestrzeni wieków, [w:] A. Gaweł, B. Bieszczada (red.), Kategorie pojęciowe edukacji w przestrzeni interdyscyplinarnych interpretacji, Wydawnictwo Uniwersytetu Jagiellońskiego, Kraków 2011, s. 73.

30 M. Bieńko, Tożsamość jako refleksyjna narracja współczesności w obszarze prywatnych i publicznych doświadczeń jednostki, [w:] R. Dopierała, K. Kaźmierska (red.) Tożsamość, nowoczesność, stereotypy, Zakład Wydawniczy Nomos, Kraków 2012, s. 142-143.

31 M. Bilewicz,Zdrowa tożsamość narodowa, https://www.kongresobywatelski.pl/idee-dla-polski-kategoria/zdrowa-tozsamosc-narodowa/ (dostęp: 14. 05. 2018). 
się procesualnie uświadomionej właściwości, opierającej się na poczuciu wolności, kształtującej się w danej kulturze społecznej, politycznej i prawnej, z którą w państwie demokratycznym identyfikuje się jednostka. W jej tworzeniu istotne znaczenie mają odniesienia historyczne i współczesne, własna biografia, nabyta wiedza, umiejętności społeczne oraz przyjęty i internalizowany system wartości społecznych i moralnych jako podbudowa w rozpoznawaniu własnych możliwości do podejmowania odpowiedzialnie aktywności i uczestnictwa w życiu społeczeństwa.

Rozszerzanie się sfery życiowej człowieka, przemieszczanie migracyjne, a także komunikacja medialna wpływają również na możliwość redefinicji własnej obywatelskości i jej uwielokrotniania oraz konstruowania na podstawie więzi ze społecznością na poziomie lokalnym, jak i na poziomie pozapaństwowym - europejskim i globalnym.

\section{Tożsamość obywatelska jako zadanie edukacyjne}

$\mathrm{Na}$ polu edukacji tożsamość obywatelska umieszczana powinna być jako jedno z zadań wyznaczonych szkole i łączyć się ściśle z wychowaniem obywatelskim. Na ten aspekt wychowania i jego znaczenie w rozwoju osobowości dzieci i młodzieży zwracano szczególną uwagę w okresie przemian ustrojowych w Polsce po 1989 roku. Wobec występującego deficytu obywatelskości wskazywano wówczas potrzebę podjęcia wysiłku do odnowy aktywności obywatelskiej, określania na nowo roli obywatela i poszukiwania źródeł konstruowania oraz rekonstruowania tożsamości obywatelskiej ${ }^{32}$. W pytaniach o kształt edukacji obywatelskiej formułowanych na łamach czasopisma „Wychowanie Obywatelskie” uświadamiano konieczność zmiany dotychczas stosowanych form i treści tego zakresu wychowania dzieci i młodzieży realizowanego przez szkołę ${ }^{33}$. Wobec problemów - jaka powinna być szkoła? i jakie wychowanie obywatelskie?, m.in proponowano:

32 Z. Kwieciński, Demokracja jako wyzwania i zadania edukacyjne, [w:] Z. Melosik, K. Przyszczypkowski (red.), Wychowanie obywatelskie. Studium teoretyczne, porównawcze i empiryczne, Wydawnictwo Edytor, Poznań - Torun 1998, s. 18.

33 Jaka szkoła? Jakie wychowanie obywatelskie, oprac. i przyg. S. Garwacki, T. Pióro, B. Misiewicz, „Wychowanie Obywatelskie” 1989, nr 9-10, s. 656-682. 
- kształcenie człowieka aktywnego, twórczo zbuntowanego wobec rzeczywistości, który wychodziłby naprzeciw nowym tendencjom politycznym, prądom etycznym, intelektualnym ${ }^{34}$,

- wychowanie do współżycia w społeczeństwie przez uświadamianie konieczności pozbywania się agresji, zawiści i lęków na rzecz zaufania w szkole i poza jej otoczeniem, uczenie „by nam się ze sobą żyło lepiej"35.

Edukację do życia w społeczeństwie i wychowanie obywatelskie jako działania potrzebne w ramach socjalizacji z udziałem szkoły podkreślał Zbigniew Kwieciński ${ }^{36}$. Wypowiadając się w tej kwestii stwierdził: „mamy okazję do czegoś zupełnie nowego - uczyć myśleć politycznie, uczyć wyobraźni politycznej, uczyć odwagi cywilnej, m.in. przez interpretację tekstu historycznego czy zdarzenia politycznego"37. Jako zadanie edukacyjne wskazywał także przygotowanie uczniów do podejmowania różnych form działania społecznego i politycznego, udział w samorządności, a także włączanie w prace na rzecz społeczności szkolnej i środowiska lokalnego ${ }^{38}$.

Z dyskursu wokół wychowania obywatelskiego należy przypomnieć wypowiedź Zbyszko Melosika, który naświetlił zagadnienie tożsamości obywatelskiej, interpretując jej znaczenie w kontekście historycznym („czasu”) i uwarunkowań przestrzeni („geografii”) ${ }^{39}$. Uświadamiał, że to pojęcie musi ulegać zmianie.

Człowiek żyje bowiem równocześnie w wielu odmiennych i kontekstualnie zdefiniowanych czasach i przestrzeniach, które posiadają różne właściwości (mapa i zegar straciły więc bezpowrotnie swoje absolutne znaczenie). Jest jednocześnie obywatelem w społeczności lokalnej, narodowej, etnicznej, państwowej, kontynentalnej i globalnej. Fragmentaryzacja tożsamości współczesnej jednostki prowadzi bez wątpienia do zmniejszenia tożsamości państwowo-narodowej (związanej z oświeceniową

34 Ibidem, s. 664-665 (wypowiedź Romana Smolskiego).

35 Ibidem, s. 660-662 (wypowiedź M.A. Falińskiego); por. ibidem, s. 673-674 (wypowiedź T. Morawskiego).

36 Ibidem, s. 662 (wypowiedź Z. Kwiecińskiego).

37 Ibidem. Por. K. Wereszczyńska, W trosce o wychowanie obywatelskie. Społeczne i pedagogiczne funkcje czasopisma „Społeczeństwo Otwarte” 1990-1998, Wydawnictwo Uniwersytetu Opolskiego, Opole 2017, s. 31-33.

38 Z. Kwieciński, Demokracja jako wyzwania i zadania edukacyjne, [w:] Wychowanie obywatelskie. Studium teoretyczne..., s. 9-13, 21.

39 Z. Melosik, Obywatelstwo, czas (historia) i przestrzeń (geografia), [w:] Wychowanie obywatelskie. Studium teoretyczne..., s. 57-65. 
interpretacją czasu i przestrzeni). Ma to też bez wątpienia ogromny wpływ na wyłaniające się formy wychowania obywatelskiego ${ }^{40}$.

Wprowadzenie zmian w edukacji jako zadanie skierował autor w stronę pedagogiki, a widział je jako wypracowanie takiej koncepcji wychowania obywatelskiego, która uwzględniałaby wartości narodowe i państwowe, włączając je w obszar współczesnych znaczeń i zjawisk społecznych, politycznych, kulturowych, wielokulturowych - „globalnych"41. W kształceniu młodego pokolenia Zbyszko Melosik i Tomasz Szkudlarek wskazywali istotne znaczenie kultury, również kultury popularnej. Uświadamiali, że: „Edukacja - rozumiana jako społeczna praktyka konstruowania znaczeń nadających sens ludzkiej tożsamości - nie jest zasadniczo odróżniana od kultury: stanowi jej aspekt, jej wymiar formacyjny przenikający rozmaite kulturowe "produkcje»"42. Potrzeby nowej filozofii edukacyjnej podkreślał Tadeusz Lewowicki. Wyrażał pogląd, że w ustroju demokratycznym edukacja powinna służyć obywatelom, którzy mają prawo we wzajemnych uzgodnieniach uczestniczyć w kontroli nad edukacją i z udziałem swoich przedstawicieli wpływać na jej cele, treści i metody ${ }^{43}$. Zdaniem autora, jednostka może rozwijać się i przygotowywać do obywatelstwa wówczas, kiedy będzie traktowana podmiotowo, a prowadzoną edukację adaptacyjną zastąpi edukacja krytyczna, czerpiąca z nurtów bliskich pedagogice dialogu, pedagogice wyzwolenia i pedagogice humanistycznej. W edukacyjnych działaniach krytyczno-kreacyjnych Lewowicki widział możliwość kształtowania jednostki pełnomocnej, zdolnej rozumieć zasady demokracji, świadomej swych kompetencji obywatelskich ${ }^{44}$. Kazimierz Przyszczypkowski, w studium teoretyczno-empirycznym - Edukacja dla demokracji omawiając związki edukacji z polityką i ideologią ustosunkował się do strategii edukacyjnych i stwierdził, że w większości były to propozycje „polityczno-administracyjne”, a występujące obok nich strategie opracowywane przez nauczycieli, jak i inne

\footnotetext{
$40 \quad$ Ibidem, s. 60.

41 Ibidem, s. 63-65.

42 Z. Melosik, T. Szkudlarek, Kultura, tożsamość i edukacja-migotanie znaczeń, Oficyna Wydawnicza „Impuls”, Kraków 1998, s. 115.

43 T. Lewowicki, Przemiany oświaty. Szkice o ideach i praktyce edukacyjnej, Wydawnictwo Akademickie Żak, Warszawa 1997, s. 16.

44 Ibidem, s. 20-21.
} 
o charakterze cząstkowym, wnoszące zmiany w zakresie metodyki, technologii i celów kształcenia, cechował „brak komplementarności”" Uzasadniał to niedostatkiem współpracy i słabej integracji przedstawicieli różnych środowisk politycznych, naukowych i społecznych, mogących decydować o kształcie edukacji obywatelskiej. W świetle wyników uzyskanych z badań nad kompetencjami obywatelskimi w wybranych środowiskach stwierdził, że edukację obywatelską na rzecz społeczności lokalnej należy rozpatrywać „w szerszej perspektywie”, jako problem ogólnospołeczny „polityki w skali makro"46. Poprzez edukację widział możliwość ukierunkowywania zmian w mentalności społeczeństwa i kształtowanie kompetencji obywatelskich. Te kompetencje określał „postawą aktywną z wyboru”, niewymuszoną, uwidocznioną w poznawczej i normatywnej gotowości działań „na rzecz dobra

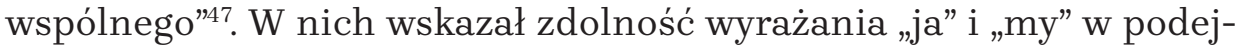
mowaniu wzajemnych zobowiązań. Tak określone kompetencje cechuje dynamiczność w zmierzaniu się człowieka z własnym losem, pokonywaniu „narzucanych ograniczeń, w uczestnictwie w zmianach w bliższym i dalszym otoczeniu ${ }^{48}$. Dyskurs nad ukierunkowaniem edukacji w demokracji i dla demokracji odsłaniał również podłoże deficytu $\mathrm{w}$ postawach obywatelskich Polaków, naświetlał obraz oświaty i polityki oświatowej oraz stan przygotowania nauczycieli do tego trudnego zadania. Ten obszar edukacji określany wychowaniem obywatelskim został poddany wieloaspektowym badaniom. W opracowanym studium teoretycznym, poznawczym, empirycznym zarazem krytycznym i konstruktywnym ${ }^{49}$ został przedstawiony materiał dostarczający wiedzy na temat podstaw wychowania obywatelskiego, znaczenia obywatelskości, tożsamości obywatelskiej i koncepcji ich wdrażania w różnych projektach wychowania obywatelskiego, z którego jak uważał Melosik, „rezygnować nie należy”, decyzja o rezygnacji bowiem

$\overline{45}$ K. Przyszczypkowski, Edukacja dla demokracji. Strategie zmian a kompetencje obywatelskie, Wydawnictwo Edytor, Torun - Poznań 1999, s. 8-28, 148.

46 Ibidem, s. 83, 85.

47 Ibidem, s. 123.

48 Ibidem.

49 Z. Melosik, K. Przyszczypkowski (red.), Wychowanie obywatelskie. Studium teoretyczne, porównawcze i empiryczne, Wydawnictwo Edytor, Toruń - Poznań 1998. 
„spowodowałaby «cięcie» socjalizacyjne" ${ }^{50}$. Edukacja wymagała jednak rekonstrukcji dotychczasowych programów i sposobów realizowania $\mathrm{w}$ formalnym kształceniu szkolnym ${ }^{51}$. Prezentując możliwą zmianę w tym zakresie edukacji autor przybliżył ją w kontekście uwarunkowań wynikających z założeń ponowoczesności. Ideę rekonstrukcji dotychczasowej edukacji obywatelskiej interpretował m.in. w świetle poglądów i rozważań Lawrenca Grossberga ${ }^{52}$, aktualnych współcześnie i wartych rozważenia $\mathrm{w}$ dyskursie pedagogów nad dalszym poszukiwaniem i wypracowaniem alternatywnych projektów, umożliwiających działania wychowawcze w oparciu o uwarunkowania rzeczywistości, tworzonej przez społeczeństwo, kształtowanej pod wpływem polityki z uwzględnieniem przemian kulturowych we współczesnym świecie, nie ignorując znaczenia kultury popularnej. W przedstawionej propozycji można odczytać inną niż dotychczas rolę pedagoga, który zamiast "wwszystko wiedzącego» metanarratora” mógłby wychowankom proponować własne ujęcia tej edukacji, przy czym w narracjach podejmować ich uzasadnienia i negocjować rekonstrukcje, będąc przy tym świadomy, że „rzeczywistość społeczna i wszelkie «prawdy» są konstruowane społecznie"53. Interpretując podejście tego autora do sposobu ustalania kształtu tożsamości, w pierwszym ujęciu można założyć, że będzie ona tworzona według jedynej koncepcji pedagoga, uznanej przez niego jako „dobra” i w takiej wersji narzucona przez niego wychowankom ${ }^{54}$. W drugim rozumieniu tego zagadnienia przy założeniu, że „źródłowa tożsamość” nie istnieje, a jej kształtowanie nie zachodzi na płaszczyźnie dochodzenia przez pedagoga „«autentyczności» lub «zniekształcenia»", istotne jest znaczenie „różnicy i reprezentacji”, przy czym „różnica sama w sobie, jak również kształt tożsamości wynika ze stosunków wiedzy/władzy w społeczeństwie oraz całej gamy społecznych i kulturowych procesów ${ }^{55}$. W warunkach, kiedy tożsamość kształtuje się w otoczeniu społecznym -

\footnotetext{
50 Z. Melosik, Wychowanie obywatelskie: nowoczesność, ponowoczesność (próba konfrontacji), [w:] Wychowanie obywatelskie. Studium teoretyczne..., s. 52-53.

51 Ibidem.

52 L. Grossberg, We Gotta Get out of This Place: Popular Conservatism and Postmodern Culture, Routledge, New York 1992, s. 90-91.

53 Z. Melosik, Wychowanie obywatelskie..., s. 54.

54 Ibidem, s. 55.

55 Ibidem.
} 
„związana jest więc z dystrybutywną mapą terenu społecznego", pedagogika nie może „«odgórnie» definiować swoich rezultatów. (...) powinna oferować jedynie punkty wyjścia (lecz nie dojścia) «odmiennej organizacji przestrzeni możliwości» w zakresie wychowania obywatelskiego i wartości obywatelskich"56. To wskazanie koresponduje ze stanowiskiem Bogusława Śliwerskiego, który podkreślił rolę pedagogiki i jej znaczenie jako nauki dostarczającej źródeł wiedzy o wychowaniu i kształceniu, pochodzących z badań teoretycznych, przyjętych ustaleń zarówno z przeszłości, jak i wnoszonych w nowych nurtach pedagogicznych. Wiedza o znaczeniu historycznym, w pewnym stopniu nadal aktualna oraz nowe propozycje składają się na przestrzeń pedagogiki „ciągle otwartą" do możliwych porównań, rekonstrukcji i zmian, również na polu interdyscyplinarnym ${ }^{57}$. Tak rozumiana rola pedagogiki i działań pedagogów znajdowały odzwierciedlenie w wypowiedziach i propozycjach odnoszących się do edukacji obywatelskiej oraz w refleksjach nad kształtowaniem osobowości i tożsamości młodego pokolenia Polaków, w ostatniej dekadzie XX wieku, jak i współcześnie. Do kontynuowanej współcześnie dyskusji swój głos m.in. włączali: Zbigniew Kwieciński, Eugenia Potulicka, Mirosław J. Szymański, Jerzy Nikitorowicz, Tomasz Szkudlarek, Piotr Gliński, Agnieszka Cybal-Michalska, Alina Szczurek-Boruta, Mirosława Nowak-Dziemianowcz, Alicja Szerląg, a także inni humaniści. Z licznego grona osób uczestniczących w interdyscyplinarnej wielowątkowej debacie poświęconej wychowaniu obywatelskiemu należy również wymienić Marię Dudzikową i Marię Czerepaniak-Walczak, inicjatorki i redaktorki tomów poświęconych wychowaniu, a w szczególności czwartego z nich Wychowanie. Pojęcia. Procesy. Konteksty, przeznaczonego w znacznej części na wypowiedzi związane, jak piszą autorki: „z kwestią «bycia» współcześnie obywatelem i patriotą oraz ze szkołą jako terenem

56 Ibidem. Por. L. Grossberg, Introduction: Bringin” It All Back Home-Pedagogy and Cultural Studies, [w:] H.A. Giroux, P. McLaren (red.), Between Borders. Pedagogy And The Politics of Cultural Studies, Routledge, New York 1994, s. 12-21.

57 B. Śliwerski, Odnajdywanie tożsamości pedagogiki w ponowoczesnym świecie i nauce, [w:] A. Cybal-Michalska (red.), Tożsamość w kontekście edukacyjnym i społeczno-kulturowym. Między partykularyzmem a uniwersalizmem, Wydawnictwo Naukowe Uniwersytetu Adama Mickiewicza, Poznań 2011, s. 27. 
doświadczeń uczniów w tym względzie"58. W refleksji nad określaniem nowego kształtu edukacji obywatelskiej, którą jako zadanie powinna realizować szkoła mogą być także wypowiedzi zawierające materiały pochodzące $\mathrm{z}$ badań nad zawartością podstawy programowej kształcenia ogólnego, dokumentu obowiązującego w szkołach ponadpodstawowych, odnoszącego się do wiedzy o społeczeństwie i wychowania obywatelskiego. Od wprowadzenia w 1999 roku reformy systemu oświatowego podstawa programowa podlegała kilkakrotnie zmianom, wychowanie obywatelskie nie było jednak znacząco rekonstruowane. Tutaj pragnę nawiązać do badań przeprowadzonych przez zespoły pracowników i doktorantów Katedry Pedagogiki Szkolnej Uniwersytetu Mikołaja Kopernika w Toruniu w ramach programu Unii Europejskiej Erasmus + Partnerstwo Strategiczne - projektu Improving Teaching Methods for Europe (IMTeaM4EU) ${ }^{59}$. Źródłem badań była podstawa programowa z 2012 roku $^{60}$. Hanna Solarczyk-Szwec, Violetta Kopińska i Anna Matusiak przeprowadziły analizę krytyczną podstawy programowej kształcenia ogólnego dla IV etapu edukacyjnego, a jako przedmiot badań przyjęły reprezentację kompetencji społecznych i obywatelskich w zawartości tego dokumentu. Na podstawie uzyskanych wyników spośród szesnastu kategorii określających oczekiwane efekty kształcenia w zakresie rozwoju społecznego, jedenaście nie wystąpiło w ogóle lub tylko raz. Były to m.in.: „umiejętność uczestnictwa w demokratycznych procesach podejmowania decyzji na poziomie lokalnym, krajowym i europejskim”; „umiejętność zaangażowania się wraz z innymi w działania publiczne”; "gotowość do przyjmowania odpowiedzialności związanej z uczestnictwem w różnych wspólnotach, funkcjonowaniem w różnych rolach społecznych"; „zainteresowanie komunikacją międzykulturową"61. Wśród wszystkich

58 M. Dudzikowa, M. Czerepaniak-Walczak, Ku demokracji poprzez edukacje, [w:] M. Dudzikowa, M. Czerepaniak-Walczak (red.), Wychowanie. Pojęcia. Procesy. Konteksty, t. 4, GWP, Gdańsk 2008, s. 7-15.

59 H. Solarczyk-Szwec, V. Kopińska, A. Matusiak, Kompetencje społeczne na wejściu $w$ dorosłość. Krytyczna analiza podstawy programowej kształcenia ogólnego dla IV etapu edukacyjnego, „Edukacja Dorosłych” 2016, nr 2, s. 29-44.

60 Rozporządzenie Ministra Edukacji Narodowej z dnia 27 sierpnia 2012 r. w sprawie podstawy programowej wychowania przedszkolnego oraz kształcenia ogólnego w poszczególnych typach szkół, Dz.U. 2012, poz. 977.

61 H. Solarczyk-Szwec, V. Kopińska, A. Matusiak, Kompetencje społeczne na wejściu $w$ dorosłość..., s. 37. 
badanych wymagań ( $\mathrm{N}=264)$ kategorie łączące się z efektami rozwoju społecznego i uzyskiwaniem kompetencji społecznych ucznia wystąpiły tylko w 46 sformułowaniach podstawy programowej kształcenia ogólnego. Z kręgu badań realizowanych w obrębie wymienionego projektu do analizy podstawy programowej sformułowany został również problem: „Czy podstawy programowe kształcenia ogólnego zakładają rozwijanie u uczniów i uczennic postaw opartych na wartościach demokratycznych/istotnych dla demokracji?"62. Jak wynika z dokonanej analizy sfera aksjologiczna w tym dokumencie została słabo wyróżniona. W ocenie Violetty Kopińskiej, „uzyskane wyniki nie dają podstaw do tego, by stwierdzić, że podstawy programowe generalnie zakładają kształtowanie wartości demokratycznych, a tym bardziej, że eksponują owe wartości w edukacji. Tak nie jest”63. Z uwag łączących się z kolejnym problemem badawczym: „Czy podstawy programowe kształcenia ogólnego zakładają osiągnięcie takich efektów uczenia się, które są istotne dla rozwijania nowoczesnego patriotyzmu?" ${ }^{4}$ wynika, że podstawą szkolnej edukacji społecznej, w szczególności przygotowania uczniów do rozumienia i urzeczywistniania patriotyzmu w jego nowoczesnej formie jest przede wszystkim przekazywana wiedza. Autorki na podstawie zebranych danych stwierdzały, że realizacja tych zakresów kształcenia szkolnego, które były przedmiotem analizy, cechuje w przewadze funkcja adaptacyjna - przekazywanie wiedzy. Uznano też, że podstawa programowa w obszarach odnoszących się do kompetencji społecznych i obywatelskich wymaga uzupełnienia i uszczegółowienia o te efekty kształcenia, które są zbieżne z rozwojem społecznym uczniów, w takim stopniu, by mogła stanowić podstawę kształtowania postaw i umiejętności w toku edukacji szkolnej, ważnych w życiu społecznym. Należy dodać, że także wcześniejsza podstawa programowa z 2002 roku była poddawana analizie w zakresie edukacji

62 V. Kopińska, Wartości demokratyczne w szkole. Krytyczna analiza podstaw programowych kształcenia ogólnego, „Rocznik Pedagogiczny” 2016, nr 39, s. 57.

63 Ibidem, s. 63.

64 V. Kopińska, K. Majchrzak, A. Szwech, Patriotyzm w edukacji szkolnej. Założenia podstaw programowych kształcenia ogólnego, „Teraźniejszość - Człowiek - Edukacja” 2017, t. 20, nr 1, s. 93. 
obywatelskiej ${ }^{65}$. Pragnę nadmienić, że w ramach badań własnych przeprowadziłam analizę najnowszej wersji podstawy programowej kształcenia ogólnego dla liceum ogólnokształcącego w zakresie przedmiotu szkolnego - wiedza o społeczeństwie, wydanej na podstawie Rozporządzenia Ministra Edukacji Narodowej z dnia 3 stycznia 2018 r. - Dz.U. 2018, poz. 467. Uzyskane wyniki pozwalają stwierdzić, że ten obszar kształcenia w nowym ustroju szkolnym przewidziano do realizacji uwzględniając przede wszystkim funkcję adaptacyjną. W małym zakresie wskazywane jest kształtowanie umiejętności potrzebnych w życiu publicznym, łączących się $\mathrm{z}$ prospołecznością i działaniem wspólnotowym. Natomiast wyznaczone treści z zakresu ustawodawstwa powinny być ponownie poddane weryfikacji, ponieważ obejmują zbyt obszerny zasób wiedzy prawnej.Z korzyścią dla ucznia warto rozważyć dokonanie wyboru najważniejszych, potrzebnych i stosowanych w życiu codziennym ustaw i przepisów.

\section{W podsumowaniu}

Z wypowiedzi o konieczności rekonstrukcji kształcenia i wychowania, także edukacji obywatelskiej pochodzi szereg krytycznych ocen, propozycji i koncepcji. Brakuje natomiast spójności w określeniu diagnozy stanu faktycznego edukacji obywatelskiej. Taka diagnoza może przyczynić się do wskazania kierunku, jaki należy nadać staraniom o jakość wychowania obywatelskiego, naświetlić rzeczywisty obraz warunków i działania szkoły w tym zakresie, wykazać stan braków i ich przyczyny. Mirosława Nowak-Dziemianowicz wyrażając swój pogląd w dyskusji na temat: „Edukacja ku obywatelskości”, uświadamia istotność działań do zmian mentalno-kulturowych w społeczeństwie, kierując szczególną uwagę na potrzebę badań nad tą edukacją ${ }^{66}$. Uzasadniając swoje stanowisko pisze:

65 C. Czech, Tożsamość obywatelska w dobie globalizacji oraz próby jej kształtowania w świetle założeń podstawy programowej z edukacji obywatelskiej - model polski i francuski, „Przegląd Pedagogiczny” 2009, nr 2, s. 90-101; K. Wereszczyńska, Uwarunkowania i efekty nauczania - uczenia się wiedzy o społeczeństwie, Wydawnictwo Uniwersytetu Opolskiego, Opole 2011, s. 141-158.

66 M. Nowak-Dziemianowicz, (Głos w dyskusji), Edukacja ku obywatelskości. Sonda internetowa, oprac. G. Woroniecka, „Societas/Communitas” 2013, nr 2, s. 30-31, 36. 
Potrzebne są dzisiaj deskryptywne i krytyczne badania nad edukacją i wychowaniem. Deskryptywne dadzą diagnozę tego, co dzieje się faktycznie na różnych poziomach edukacji. Badaniami trzeba objąć wszystkich uczestników procesów edukacji: nauczycieli, rodziców, uczniów, władze oświatowe. Badane powinny być ich edukacyjne oczekiwania i potrzeby, a także pewien wzór kulturowy myślenia o szkole i edukacji. Badania krytyczne pozwoliłyby zrekonstruować założenia legitymizujące różne praktyki edukacyjne w naszym kraju ${ }^{67}$.

Jeżeli oczekujemy zmian w edukacji i jej unowocześnienia, by młodzież uzyskiwała odpowiednie przygotowanie do życia w warunkach lokalnych i globalnych, to konieczna jest kontynuacja otwartego, twórczego dyskursu i jednocześnie rozpoczęcie kompleksowych badań nad tym ważnym problemem. Tym bardziej ważnym współcześnie ze względu na występujące bardzo wyraźnie indywidualizację i konsumpcyjny styl życia oraz deficyty w sferach obywatelskości i kształtowania się społeczeństwa obywatelskiego. W rozważaniach o edukacji nie powinno zabraknąć nowych myśli i koncepcji wskazujących możliwe działania jednostki o wspólnotowym znaczeniu, według jej własnych przekonań, celowych i rzeczywistych, których będzie czuła się odpowiedzialnym sprawcą. Takie zadanie może podjąć tylko „szkoła otwarta" przygotowana do realizacji idei podmiotowości, otwierająca się na uznanie pełnej autonomii nauczyciela oraz podmiotowości jego i ucznia ${ }^{68}$. Autentyczna obustronna podmiotowość powinna polegać na wzajemnym uznaniu, tak rozumiana, zdaniem Jerzego Niemca, „może być wielce pomocna współcześnie i na przyszłość, dla właściwego rozwoju, przyjaznych człowiekowi systemów edukacyjnych"69. Ochrona podmiotowości, ubogacanie tożsamości jednostki i jej tożsamości obywatelskiej o nowe wartościowe wzmocnienia do odpowiedzialnego uczestnictwa w działaniach wspólnoty, w demokracji są zadaniami, którym trzeba w edukacji nadawać ważne znaczenie, uwzględniając zachodzące zmiany mentalno-kulturowe w społeczeństwie i krytycznie oceniając rzeczywistość.

\footnotetext{
67 Ibidem, s. 36 .

68 J. Niemiec, Szkoła jako instytucja otwarta, [w:] B. Muchacka (red.), Szkoła w nauce i praktyce edukacyjnej, t. 1, Oficyna Wydawnicza „Impuls”, Kraków 2006, s. 121.

69 J. Niemiec, Podmiotowość w intencjach edukacyjnych, [w:] J. Niemiec, A. Popławska (red.), Podmiotowość we współczesnej edukacji. Oglady - intencje - realia, Wydawnictwo Niepaństwowej Wyższej Pedagogicznej w Białymstoku, Białystok 2009, s. 13.
} 


\begin{abstract}
The issues indicated by the title of this article have been presented in two parts. The first one refers to the meaning of identity in terminological terms - linguistic and processual, combined with human development and its identifying self-description in a social and cultural context. Also here, a reference has been made to selected theoretical, definitional terms and interpretations of the categories: identity, individual identity, social identity, and civic identity. The second part discusses the issue of shaping and reinforcing the civic identity of the young generation, i.e. the youth on the verge of adulthood, as an educational task and civic upbringing with the participation of the school.
\end{abstract}

\title{
Bibliografia
}

Babiński G., Pogranicze polsko-ukraińskie. Etniczność, zróżnicowanie religijne, tożsamość, Zakład Wydawniczy Nomos, Kraków 1997.

Bartczak J., Wymiary tożsamości, [w:] A. Firkowska-Mankiewicz, T. Kanash, E. Tarkowska (red.), Krótkie wykłady z socjologii. Kategorie, problemy, subdyscypliny, t. 2: kontynuacja, Wydawnictwo Akademii Pedagogiki Specjalnej im. Marii Grzegorzewskiej, Warszawa 2010.

Bauman Z., 44 listy ze świata płynnej nowoczesności, Wydawnictwo Literackie, Kraków 2011.

Bauman Z., Ponowoczesne wzory osobowe, „Studia Socjologiczne” 1993, nr 2.

Bieńko M., Tożsamość jako refleksyjna narracja współczesności w obszarze prywatnych i publicznych doświadczeń jednostki, [w:] R. Dopierała, K. Kaźmierska (red.), Tożsamość, nowoczesność, stereotypy, Zakład Wydawniczy Nomos, Kraków 2012.

Bokszański Z., Tożsamości zbiorowe, Wydawnictwo Naukowe PWN, Warszawa 2006.

Bralczyk J. (red.), Słownik 100 tysięcy potrzebnych słów, Wydawnictwo Naukowe PWN, Warszawa 2005.

Czech C., Tożsamość obywatelska w dobie globalizacji oraz próby jej kształtowania $w$ świetle założeń podstawy programowej z edukacji obywatelskiej - model polski i francuski, „Przegląd Pedagogiczny” 2009, nr 2.

Dudzikowa M., Czerepaniak-Walczak M., Ku demokracji poprzez edukacje, [w:] M. Dudzikowa, M. Czerepaniak-Walczak (red.), Wychowanie. Pojęcia. Procesy. Konteksty, t. 4, GWP, Gdańsk 2008.

Erikson E.H., Dzieciństwo i społeczeństwo, tłum. P. Hejmej, Dom Wydawniczy REBIS, Poznań 1997. 
Erikson E.H., Identity. Psychosocial, [w:] D.L. Sills (red.), International Encyclopedia of The Social Science, t. 7, The MacMillan Company \& The Free Press, New York 1968.

Giddens A., Nowoczesność i tożsamość. „Ja” i społeczeństwo w epoce późnej nowoczesności, tłum. A. Szulżycka, Wydawnictwo Naukowe PWN, Warszawa 2010.

Giddens A., Sutton Ph.W., Socjologia. Wydanie nowe, tłum. O. Siara, A. Szulżycka, P. Tomanek, Wydawnictwo Naukowe PWN, Warszawa 2012.

Golka M., Cywilizacja współczesna i globalne problemy, Oficyna Naukowa, Warszawa 2012.

Grossberg L., Introduction: Bringin" It All Back Home-Pedagogy and Cultural Studies, [w:] H.A. Giroux, P. McLaren (red.), Between Borders. Pedagogy And The Politics of Cultural Studies, Routledge, New York 1994.

Grossberg L., We Gotta Get out of This Place: Popular Conservatism and Postmodern Culture, Routledge, New York 1992.

Grzebieniowski T., Ilustrowany słownik angielsko-polski, polsko-angielski, Państwowe Wydawnictwo Wiedza Powszechna, Warszawa 1979.

Jaka szkoła? Jakie wychowanie obywatelskie, oprac. i przyg. S. Garwacki, T. Pióro, B. Misiewicz, „Wychowanie Obywatelskie” 1989, nr 9-10.

Kłoskowska A., Tożsamość i identyfikacja narodowa w perspektywie historycznej i psychologicznej, „Kultura i Społeczeństwo” 1992, nr 1.

Kopińska V., Majchrzak K., Szwech A., Patriotyzm w edukacji szkolnej. Założenia podstaw programowych kształcenia ogólnego, „Teraźniejszość - Człowiek - Edukacja” 2017, t. 20, nr 1.

Kopińska V., Wartości demokratyczne w szkole. Krytyczna analiza podstaw programowych kształcenia ogólnego, „Rocznik Pedagogiczny” 2016, nr 39.

Kwieciński Z., Demokracja jako wyzwania $i$ zadania edukacyjne, [w:] Z. Melosik, K. Przyszczypkowski (red.),Wychowanie obywatelskie. Studium teoretyczne, porównawcze i empiryczne, Wydawnictwo Edytor, Poznań - Toruń 1998.

Lewowicki T., Przemiany oświaty. Szkice o ideach i praktyce edukacyjnej, Wydawnictwo Akademickie Żak, Warszawa 1997.

Mach Z., Procesy rekonstrukcji tożsamości społecznej w krajach Europy Środkowo-Wschodniej, „Nomos” 1994, nr 7/8.

Mach Z., Przedmowa, [w:] T. Paleczny, Socjologia tożsamości, Krakowskie Towarzystwo Edukacyjne Sp. z o. o., Oficyna Wydawnicza AFM, Kraków 2008. 
Melosik Z., Obywatelstwo, czas (historia) i przestrzeń (geografia), [w:] Z. Melosik, K. Przyszczypkowski (red.),Wychowanie obywatelskie. Studium teoretyczne, porównawcze i empiryczne, Wydawnictwo Edytor, Poznań - Toruń 1998.

Melosik Z., Przyszczypkowski K. (red.), Wychowanie obywatelskie. Studium teoretyczne, porównawcze i empiryczne, Wydawnictwo Edytor, Toruń - Poznań 1998.

Melosik Z., Szkudlarek T., Kultura, tożsamość i edukacja-migotanie znaczeń, Oficyna Wydawnicza „Impuls”, Kraków 1998.

Melosik Z., Wychowanie obywatelskie: nowoczesność, ponowoczesność (próba konfrontacji), [w:] Z. Melosik, K. Przyszczypkowski (red.),Wychowanie obywatelskie. Studium teoretyczne, porównawcze i empiryczne, Wydawnictwo Edytor, Poznań - Toruń 1998.

Misztal B., Teoria socjologiczna a praktyka społeczna, Wydawnictwo Universitas, Kraków 2000.

Niemiec J., Podmiotowość w intencjach edukacyjnych, [w:] J. Niemiec, A. Popławska (red.), Podmiotowość we współczesnej edukacji. Oglą$d y$ - intencje - realia, Wydawnictwo Niepaństwowej Wyższej Pedagogicznej w Białymstoku, Białystok 2009.

Niemiec J., Szkoła jako instytucja otwarta, [w:] B. Muchacka (red.), Szkoła w nauce i praktyce edukacyjnej, t. 1, Oficyna Wydawnicza „Impuls”, Kraków 2006.

Nowak-Dziemianowicz M., (Głos w dyskusji), Edukacja ku obywatelskości. Sonda internetowa, oprac. G. Woroniecka, „Societas/Communitas" 2013, nr 2.

Ozga E., O obywatelskości i jej przemianach na przestrzeni wieków, [w:] A. Gaweł, B. Bieszczada (red.), Kategorie pojęciowe edukacji $w$ przestrzeni interdyscyplinarnych interpretacji, Wydawnictwo Uniwersytetu Jagiellońskiego, Kraków 2011.

Przyszczypkowski K., Edukacja dla demokracji. Strategie mian a kompetencje obywatelskie, Wydawnictwo Edytor, Toruń - Poznań 1999.

Rozporządzenie Ministra Edukacji Narodowej z dnia 27 sierpnia 2012 r. w sprawie podstawy programowej wychowania przedszkolnego oraz kształcenia ogólnego w poszczególnych typach szkół (Dz.U. 2012, poz. 977).

Rozporządzenie Ministra Edukacji Narodowej z dnia 3 stycznia 2018 r. w sprawie podstawy programowej kształcenia ogólnego dla liceum ogólnokształcącego, technikum oraz branżowej szkoły II stopnia (Dz.U. 2018, poz. 467). 
Shils E.A., Co to jest społeczeństwo obywatelskie?, tłum. D. Lachowska, [w:] K. Michalski (red.), Europa i społeczeństwo obywatelskie. Rozmowy w Castel Gandolfo, Wydawnictwo Znak, Kraków 1994.

Solarczyk-Szwec H., Kopińska V., Matusiak A., Kompetencje społeczne na wejściu w dorosłość. Krytyczna analiza podstawy programowej kształcenia ogólnego dla IV etapu edukacyjnego, „Edukacja Dorosłych" 2016, nr 2.

Szymański M.J., Kim jestem? Tożsamość jako zadanie w czasach gwattownej zmiany społecznej, „Lubelski Rocznik Pedagogiczny” 2016, t. 35 , z. 1.

Słownik języka polskiego, t. 1, PWN, Warszawa 1978.

Słownik języka polskiego, t. 3, PWN, Warszawa 1981.

Słownik łacińsko-polski, wg Słownika H. Mengego i H. Kopii, oprac. K. Kumaniecki, PWN, Warszawa 1964.

Śliwerski B., Odnajdywanie tożsamości pedagogiki w ponowoczesnym świecie i nauce, [w:] A. Cybal-Michalska (red.), Tożsamość w kontekście edukacyjnym i społeczno-kulturowym. Między partykularyzmem a uniwersalizmem, Wydawnictwo Naukowe Uniwersytetu Adama Mickiewicza, Poznań 2011.

Waszczyńska K., Wokół problematyki tożsamości, „Rocznik Towarzystwa Naukowego Płockiego" 2014, nr 6.

Wereszczyńska K., Uwarunkowania i efekty nauczania-uczenia się wiedzy o społeczeństwie, Wydawnictwo Uniwersytetu Opolskiego, Opole 2011.

Wereszczyńska K., W trosce o wychowanie obywatelskie. Społeczne i pedagogiczne funkcje czasopisma „Społeczeństwo Otwarte” 1990-1998, Wydawnictwo Uniwersytetu Opolskiego, Opole 2017.

\section{Netografia}

Bilewicz M., Zdrowa tożsamość narodowa, https:/www.kongresobywatelski.pl/idee-dla-polski-kategoria/zdrowa-tozsamosc-narodowa/ (dostęp: 14.05.2018). 